\title{
Factors Affecting Micro and Small-Scale Industries Income: A Case Study on Coffee Processing Industry
}

\author{
Lya Aklimawati ${ }^{1 *}$, Djoko Soemarno ${ }^{1)}$ and Surip Mawardi ${ }^{1)}$ \\ ${ }^{1)}$ Indonesian Coffee and Cocoa Research Institute, J1. PB. Sudirman No.90 Jember 68118, Indonesia \\ ${ }^{*}$ Corresponding author: lya.akli@gmail.com \\ Received: 27 April 2016 / accepted: 11 June 2016
}

\begin{abstract}
Development the competitive industries primarily small firms ought to be realized for improving economic growth of a community. Small industries have an important role especially on income equity improvement in rural areas. The objective of this study was to assess industry players motivation for developing their business in coffee processing and also to analyze factors which influence business income focused on micro and small-scale coffee industries in Bondowoso District. Survey method was used in this study for collecting primary and secondary data. A number of respondents were 25 coffee industry players who be determined by judgement sampling method. Data were analyzed by descriptive and statistic method. Multiple linear regression was used in the suspected factors that affect small industries income. The results indicated that the main motivation of industry players in initiating and developing coffee business was financial incentive. Consecutively, indicators that may explain industry player's motivation were expectation, motive and incentive. Micro and small-scale industries income was affected by raw material, marketing reach, technology and business experience. Meanwhile, micro and small-scale industries income was not affected by labor cost and source of capital.
\end{abstract}

Keywords: business income, entrepreneurial motivation, micro and small-scale industries, coffee, financial incentive, Bondowoso district

\section{INTRODUCTION}

Empowerment the small industries is an important issues to study and to develop home-income sustainably in order to accelerate regional development. The existence of small industry gives an important contribution, especially in creating regional economic development. This existence is significant as it can work as a sector which activates rural economic. Growth of the industrial groups will result in significant effect to the equality of income for rural community (Munizu, 2010). It is because the majority of the small industries still utilize natural and human resources in their area to develop their industries. Consequently, it can be said that small industry plays a strategic role in developing regional economic and optimizing the utilization of local resources to be managed commercially. Eventually, the growth of small industry is expected to be able to trigger other economic sectors and evenly distribute the result of development (Kristiyanti, 2012).

In developing small industries, agriculture sector provides many alternatives of opportunity to be developed through the utilization of agricultural commodities. One of the agricultural commodity-based industries is an industry 
of coffee bean processing. This industry is the priority industry which is prospective to be developed, regarding the fact that there is an increase in the coffee consumption due to the change of life style. Based on the ICO data (2015), the average rate of coffee consumption in Indonesia during 2006 to 2014 increased to $11.05 \%$ per year. The increased consumption of domestic coffee is one of the factors which affect the growth of local coffee shops whose market target is either middle to lower economic level or middle to upper class people. Behavioral change and cultural development in the citizen show the promising business development in the sector of coffee agroindustry.

The growth of the small industry in coffee bean processing is highly needed, particularly to improve the added value of the coffee bean product and to fulfill the need of local coffee consumption. Moreover, the development of coffee bean processing industry is one of the attempts to resolve the saturation of coffee market in the form of primary products. Through product development, coffee beans can be diversified into products which give added value, therefore it can give more benefits to the industrial actor in terms of income.

The coffee bean processing shows a rapid development, particularly in the small scale coffee bean industry in Bondowoso district. The growing industry is due to the fact that there is an implementation of the clustered-community based on coffee bean industry development program which provide various facilities to activate the economic sector. The clustered coffee bean industry development program is started with quality and marketing system improvement. The success in technology guiding in improving the quality and marketing efficiency brought a positive effect to farmers in form of higher price of coffee beans. The increased price does not limit the farmer to earn more income by doing the product diversification. Business opportunity in coffee bean processing makes farmers develop small scale industry producing the processed coffee products.

In implementing the production activities, the coffee bean industry used raw materials and other production factors which are obtained from their operational area. Easy access to the productive resources needs to be well utilized by the industry actors to improve their production capacity and develop their industry scale. The development of the coffee bean processing industry indicates that coffee bean business gives promising opportunity which improves household income. This study aims to study the industry actor's motivation to develop their business in coffee bean processing, and to analyze the factors affecting the income of small scale coffee bean industries in Bondowoso district.

\section{MATERIALS AND METHODS}

This study is a case study which was carried out in small-scale industries in the field of coffee bean processing in Suberwringin subdistrict, Bondowoso district. The research location was chosen deliberately as the coffee bean industry in the goring area rapidly due to the clustered coffee bean industry development program. Besides, Sumberwringin subdistrict was one of the areas producing coffee bean in Bondowoso district, thus, the industry actor had built personal relationship with the raw material suppliers to run the production process. This condition reflected the abundant production factors and productive resources which were well utilized by the industry actors. The survey was undertaken in August to November 2014.

This study employed primary and secondary data. The primary data were taken directly by using semi-open questionnaire distributed 
to industry actors. The information obtained from the questionnaire is production capacity $(\mathrm{kg})$, raw materials ( $\mathrm{kg}$ ), employees (people), wages (Rupiahs), industrial experiences (year), capital sources (owned or loan), use of machine and technology (properly or not properly), market range (in or outside regency), and motivation to develop coffee bean processing business. The entrepreneurship motivation will refer to three indicators mentioned in the study reported by Purnama \& Suyanto (2010), namely motive, expectation, and incentive. Attributes in motive indicator were (1) earning additional income, (2) providing job opportunity for family and community, (3) being more productive, (4) implementing ideas or creativity, and (5) receiving facilities from the government or non-governmental organization. Attributes in expectation indicator were (1) improving income, (2) improving the added value of products, (3) expanding markets, and (4) increasing number of consumers. Incentive indicator used attributes as follows (1) gaining higher income, (2) gaining selfactualization, and (3) expanding market and collaborators. Obtaining of primary data was adjusting to the respondent's answer. Meanwhile, the secondary data was obtained from literature study, internal report, and data related to the topic of study.

This study used survey method by observing directly to the object of the study in the field. The primary data was taken by direct observation, interview, and questionnaire. The primary data source was industry actors of small-industry of coffee bean. The secondary data were acquired from desk study by collecting data related with the topic from relevant sources. The secondary data were internal reports of clustered coffee bean industry development program in Bondowoso district and other supporting data. Respondents to obtain the primary data were approached by non-probability sampling; therefore the possibility to be chosen as the sample was undefined. The respondent choosing technique was done by using judgment or purposive sampling. This method was used due to the fact that the chosen respondents could represent the population and meet the criteria to give information related to the topic of study (Utomo \& Siregar, 2008; Almilia et al., 2009; Asnur, 2010). In this study, there were 44 farmer groups and 1,500 coffee farmers in the area of clustered coffee development program. The population in this study was 25 industry actors, therefore all actors became respondents in this study. Because of the limited population, the sample taken was relatively small. This small sample was due to the fact that the coffee processing industry in the area still growing.

\section{Analysis Method}

In this study, analysis method used was descriptive and statistical analysis. The descriptive analysis was done to give a picture on the problem and show relationship between the phenomena and its. This descriptive analysis was used to analyze qualitative data and study characteristic of the research objectives. The data from descriptive analysis will be shown in form of table or frequency distribution and tabulation. Besides, problems in the study will also be explained.

Statistical analysis was done to study factors affecting the small scale coffee industry income. In this analysis, multiple linier regression analysis will be used to predict factors affecting the income. Econometric model used in this study was a regression model with three dummy variables, with a equation as follows. 


$$
\ln \mathrm{Y}=\beta 1 \ln \mathrm{X} 1+\beta 2 \ln \mathrm{X} 2+\beta 3 \ln \mathrm{X} 3+\mathrm{W} 1 \mathrm{D} 1+\mathrm{W} 2 \mathrm{D} 2+\mathrm{W} 3 \mathrm{D} 3+\varepsilon \mathrm{i}
$$

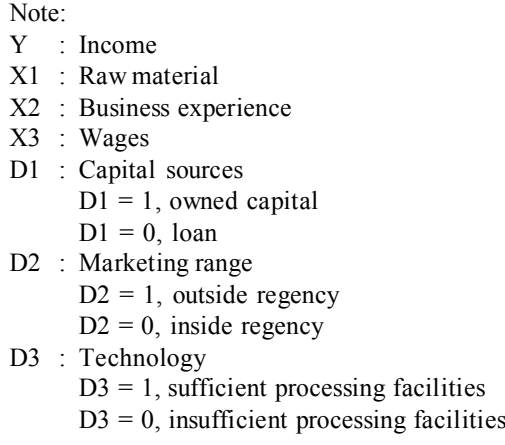

Econometric model in the equation (1) had been transformed into natural logarithm form (double log), therefore the regression coefficient would show the elasticity value from its variable. In the equation (1), the Constanta component was not included in the model to avoid multicolinearity because the qualitative variables included more than two (Rosadi, 2012). Variables used in this study referred to the study by Minuzu (2010) and Kurniawan (2008).

To detect the classic assumption deviation in the regression model equation, the diagnostic checking was carried out in order to met the regression model criteria of BLUE (best linear unbiased estimator). Diagnostic checking done in this study was (Ghozali, 2005; Santosa \& Ashari, 2007; Rosadi, 2012).

\section{A. Multicolinearity Test}

To detect the multicolinearity, the checking method used was Klein method. This method compared determination coefficient value from the main regression model and independent variable of the deceived regression. The multicolinearity occurred when determination coefficient value from the main regression model was smaller than the deceived regression model.
B. Heteroscedasticity Test

To ensure the heteroscedasticity, checking method used was White Test. The heteroscedasticity occurred when the p-value was smaller than $\alpha(p$-value $<\alpha)$, to improve the significance $5 \%$.

C. Autocorrelation Test

To detect serial correlation in residual of regression model, the Durbin Watson (DW) and Breusch Godfrey Lagrange Multiplier (BGLM) tests were done. In the DW test, the residual autocorrelation did not occur when the DW statistical value was in between the du and 4-du values. In BGLM test, autocorrelation occurred when $\mathrm{p}$-value from Obs*Rsquared was smaller than the significance degree $5 \%$ (p-value $<\alpha, \alpha=5 \%$ ).

\section{RESULTS AND DISCUSSION}

Micro and small industries in coffee processing were parts of the industries to earn income for families in Sumberwringin subdistrict, Bondowoso district. Besides coffee farming, economic life of this area relied on the coffee processing industry. This industry was growing as more people worked on the coffee business by establishing small industries. This was indicated by the increasing number of new industries which processed coffee beans. After the implementation of cluster program, there were 16 units of micro and small industries growing until 2013. Growth of the industry was a positive effect of the implementation of the clustered coffee industry facilitated by some stakeholders. The support from various stakeholders and conducive economic and social 
condition were important aspects to improve the competitiveness and grow the local-based industries (Suradisastra et al., 2004). Through the cluster program, industry actors received trainings related to coffee processing, thus, their knowledge and capacity improved. The knowledgeable farmers and industry actors became the activator for those who wanted to initiate their coffee business by understanding the existed market potential.

By studying the industrial growth, it could be seen that the entrepreneurship motivation was one of factors affecting the growth of micro and small scale coffee industry. In this study, the description of the entrepreneurship motivation referred to three indicators used by Purnama \& Suyanto (2010). They were motive (business actor's wishes in their business), expectation (the gained opportunity because of the achieved goal), and incentive (reward from the business). The finding showed that the respondent's motive in developing their coffee business was to earn some additional income. Beside the financial aspect, the industry actors also had other motives as displayed in Table 1, including being more productive $(48 \%)$, implementing ideas or creativity $(44 \%)$, receiving facilities from the government or non-governmental organization (32\%), and providing job opportunities for family and citizens (12\%). Based on those indicators, the motivation of the industry actors to run their business tended to the fulfillment of physiology needs. Only some of the actors fulfilled self-actualization and social needs as well as service to develop their business. It could be said that the motive they had was directed to the improvement of prosperity (Barba-Sánchez \& Atienza-Sahuquillo, 2012).

In the expectation indicator, the industry actor tended to wish the increased income $(100 \%)$ and added value $(68 \%)$ in opening new business in the coffee sector. They stated that processing the coffee beans into powdered coffee and or gingered coffee would add the value of the product. Furthermore, the price of processed coffee was more stable than coffee bean price. Only a few industries wished to improve their market area (24\%) and consumers (28\%). This was because the small industry could not compete with the larger industries in marketing their products, as the competition to enter the processed coffee market was very tight (BI Jember \& Puslitkoka, 2010). However, the industry

Table 1. Entrepreneurial motivation based on perception of micro and small scale coffee industri players

\begin{tabular}{clccc}
\hline & Entrepreneurial Motivation & \multicolumn{1}{c}{ Atribute } & $\begin{array}{c}\text { Number of industries } \\
\text { (unit) }\end{array}$ & \multicolumn{2}{c}{$\begin{array}{c}\text { Percentage } \\
\text { (\%) }\end{array}$} \\
\hline Indicator & \multicolumn{1}{c}{ Added income } & 25 & 100 \\
& Jobs for family and community & 3 & 12 \\
& More productive & 12 & 48 \\
& Carry out idea/creativity & 11 & 44 \\
& Obtain facilities from Government/NGO & 8 & 32 \\
Expectation & Increased income & 25 & 100 \\
& Increased product added value & 17 & 68 \\
& Increased market segment & 6 & 24 \\
Insentive & Increased customer number & 7 & 28 \\
& Higher income & 25 & 100 \\
& Self actualization satisfaction & 8 & 32 \\
\hline
\end{tabular}


actors still had some opportunity that the potential to enter the market was still appreciable due to the increased consumption of domestic coffee. One of strategies to face the competition to enter the market was by improving quality of raw material and processing method, thus the product was more qualified. The attempt to improve the quality of the product was in line with the study of Nurhayati et al. (2012). Consequently, the price of the coffee products would be higher than the price of the processed coffee product in the market.

Based on the incentive indicator, the main reason for the industry actors to start their business and develop the business scale was the high income. Less of the industry actors stated that the self-satisfaction (32\%) and marketing network (28) were the incentive they received. This suggested that in running their business, the industry actors were rarely oriented to pursue the social and service needs beside self-actualization and affiliation. The main desire was mostly oriented to make profit as they expected to get result which was equal to the time spent, investment, and risk they took in running their business.

From the three indicators of entrepreneurship motivation, it could be concluded that the main motivation to start and develop the business was financial motivation (Wijaya, 2008), especially to improve the prosperity. It could not be denied that financial incentive was one triggering factor which activated the working spirit, particularly to manage the business (Walker \& Brown, 2004; Rose \& Manley, 2011). Barba-Sánchez \& AtienzaSahuquillo (2012) also stated that economic need was the main motivation to achieve success in running business. For micro and small industries, financial incentive was a crucial thing as it could fill physiology need in daily life. On other side, the financial incentive would also affect sustainability of the business as it was related to the working capital as the tool to continue the production process. The financial incentive could also be realized in form of policies related to the supporting service in the financial area to develop micro and small scale industries (Yushuai et al., 2014). In line with the study of Purnama \& Suyanto (2010), the indicators which could tell the motivation were expectation, motive, and incentive, respectively. Expectation was the most significant motive to motivate the entrepreneur (Yushuai et al., 2014) as it was directly related to desire and final goal of the business actor. Fulfillment of the desire and goal would trigger the business actor to increase their production scale and widened the business scale.

The highly motivated business actor would do a lot of many things to create value or business opportunity to improve their income and achieve their goal. One thing they could do was implementing and developing innovation to their business activities (Yunai \& Indriyani, 2013). This could be reflected from the creation of some coffee products, such as roasted coffee, gingered coffee, and other products. Beside product variation, the coffee industry also improved their attribute such as quality of the products and packaging. At first, they did not pay much attention to the raw material they used, but by the time went by, they would improve the quality of the raw material to produce powdered coffee and roasted one. The use of medium-quality coffee beans would make different from the competitor, thus, the offered coffee product was sold in higher price. The micro and small scale industries did not only improve the quality of the raw material, but they also improved the packaging. Before the implementation of the clustered industry program, the quality of processed coffee product varied, but the packaging was very simple. Most of them was packaged in plastic with no label (BI Jember \& Puslitkoka, 2010). The improvement in terms of quality was needed to improve the competitiveness (Nurhayati 
et al., 2012) therefore the consumers were attracted to buy the product. Quality and packaging were the competitive media to add the customer value from the coffee products produced. The formulation of product variation and improved product attribute were the product innovation that was done by the micro and small scale coffee industry. As suggested by Johne cit. Nursiah \& Radhi (2009), development of product design, fiture addition and product attribute were included in the product innovation to encounter the competitor. Similar statement was also suggested by Kotler \& Armstrong (2004) that innovation in the product attribute was a tool to be superior in competing with other similar products.

With the business motivation attributes, it seemed that the most awarded attribute was one related to the income. The income earned from the coffee business was used as the activator to develop the business. In other words, orientation of business actors towards the income was one of the aspects which triggered the growing business managed by the micro and small scale industries (Juniarti \& Limanjaya, 2005; Prasetyo, 2007). The importance of income for the micro and small scale industries could become the initial base to improve the business opportunity and industry performance. In this study, some aspects related with the industry income would be studied as well. By estimating the production factor and other factors related to the income, the strategy to improve the income of micro and small scale industry could be established.

The regression equation for the micro and small scale industry could be analyzed by using $F$ test. This was to identify whether the independent variable used in the regression model affected the dependent variable simultaneously. Based on the analysis result, the value of F-statistic was 286.3550 with $\mathrm{p}$-value as much as 0.0000 . Statistically, the p-value $(0.0000)$ was smaller than the significance value $(\alpha=0.05)$. This indicated that simultaneously raw material, experience, wages, capital sources, marketing range, and technology significantly affected on the industry income.

From $\mathrm{F}$ test, it could also be identified the value of determinant coefficient or $\mathrm{R}^{2}$. Table 2 showed the value of $\mathrm{R}^{2}$ which was 0.9869 meaning that $98.69 \%$ of the income could be explained by the raw material, experience, wages, capital sources, marketing range, and technology. The rest of $1.31 \%$ was affected by other variables outside the regression model. Other variables affected potentially on income were education level, age, demand, credit, business management, social capital, product mixture, and others (Prasetyo, 2007; McCommick et al. cit. Munizu, 2010; Witjaksono, 2010).

Based on the regression analysis, raw material variable had the regression coefficient of $1.0283(\mathrm{t}$-value $=30.6401 ; \mathrm{p}$-value $=0.0000$ ). This result indicated that the raw material variable positively affected income of the industry. Based on the field condition, the supply of raw material had been concentrated thus it was easily accessed by the small industries. All industries utilized the local raw material to produce their products. Generally, the proportion of raw material was $80 \%$ sold as primary product while $20 \%$ sold as processed product. The concentrated raw material was one of the pull factors to support development and growth of the small industries (Prasetyo, 2007). This was due to the fact that the easy access to raw material would affect the fulfillment of the product capacity based on the market or consumer demand.

In the business experience variable, it could be seen that the regression coefficient value was $-0.1969(\mathrm{t}-\mathrm{value}=-3.8222 \mathrm{p}$ value $=0.0011)$. This showed that business experience affected negatively to industry. Munizu (2010) stated that in various businesses, 
Table 2. Results of significance of parameters for linear regression model on micro and small scale coffee industries income

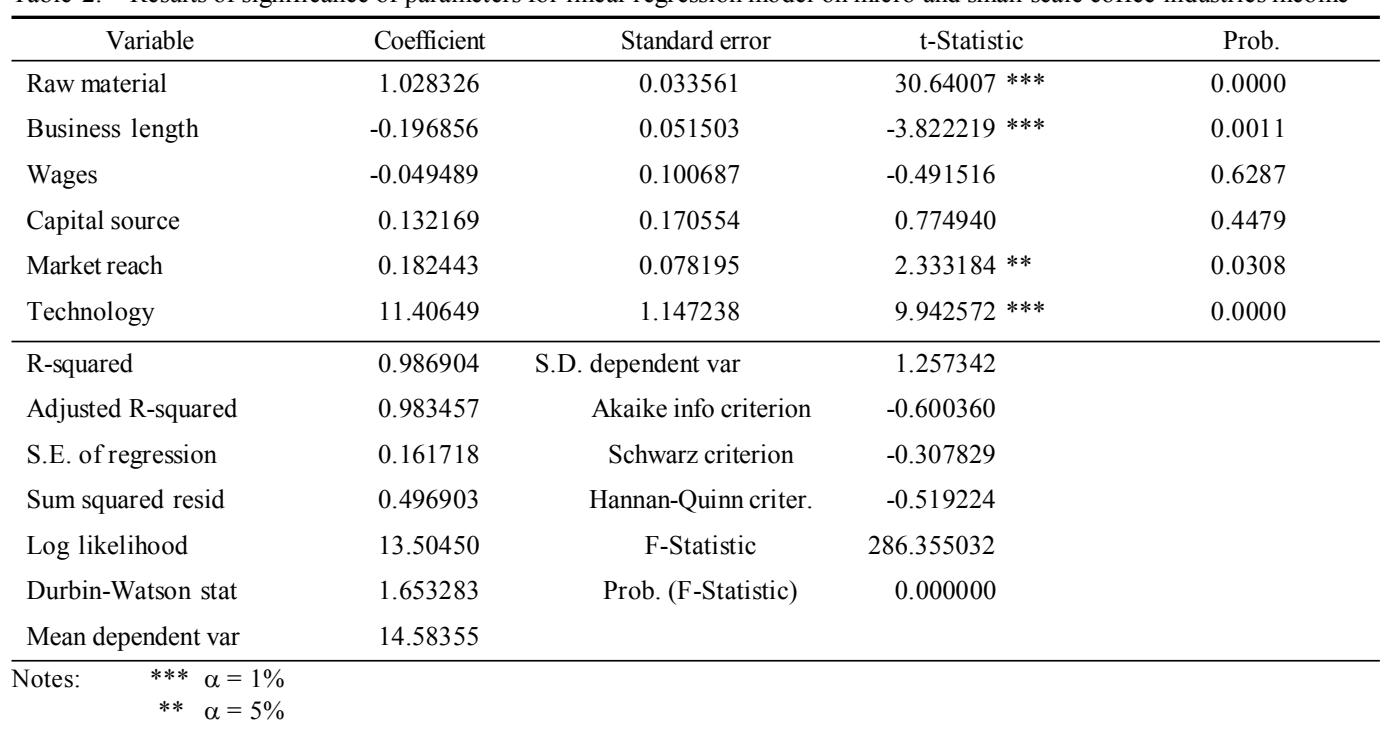

experience was the strength and main capital to develop business. The experience was related to entrepreneurship motivation and knowledge of market network. The longer the experience, the higher opportunity they had to expand the market range, compared to the new business actors.

Another variable affecting the income of the industry was market range and technology. From the regression analysis, it could be seen that the market range's regression coefficient value was 0.1824 $(\mathrm{t}$-value $=2.3332 ; \mathrm{p}$-value $=0.0308)$. This meant that market range affected positively on industry income. The effect of marketing to the industry's income was also suggested by Prasetyo (2007). Market range was related to market demand to coffee products produced by the micro and small scale industries. The wide-ranged industry indicated that market demand for their product was high, thus number of product sold was high as well. The product selling would affect the income of the micro and small scale industries.

Meanwhile, the technology variable had regression coefficient value as much as $11.4065(\mathrm{t}$-value $=9.9426 ; \mathrm{p}=0.0000)$ which suggested that technology variable affected positively to the industry income. Similar to the market range variable, Prasetyo (2007) also suggested that technology was one of factors which affected industry income. Utilization of technology would trigger the small industry to develop themselves to be better business. The existence of technology was related to the product capacity which would be reached to fulfill the consumer need. The higher the demand, the higher the income earned by the industry.

This study also showed that wages and capital source variables did not affect the industry income $(\alpha=0.1)$, because the employees were mostly relatives, therefore the industry actor did not spend some money to pay employee. For some micro and small scale industries, wages did not count as production cost as the cost was implicit and it would decrease income. Non-relative employees would be hired when the production capacity was high and the production activity could not be handled by the relatives. Besides, the industry actor whose business orientation was wide would hire more nonrelative employees. 
Capital source also did not affect the industry income as it was owned or family capital. Only a few of the industry actors started and developed their business using loan. They would rather start the business by using their own money (Munizu, 2010). The owned capital was the implicit cost which affected the income. The implicit cost was in form of owned interest. However, most of the industry actors did not calculate the cost as it could decrease income. Moreover, the industry actors also assumed that the loan would burden the cash flow of their finance as they had to pay back the loan in certain time in form of regular installment.

The evaluation towards the regression equation model of the income could be done by the classical testing, which was the heteroskedasticity, autocorrelation, and multikolinearity tests. The heteroskedasticity test showed the value of White test as much as 3.982619 with p-value as much as 0.5519 . In the significance value as $5 \%$, in could be concluded that error variant has been constant as the p-value was larger than alpha $5 \%$, thus, the heteroskedasticity assumption could be met.
The next classical assumption test was the test to see the correlation in the residual or the autocorrelation. Based on the output in Table 3, it could be that the BGLM statistic value was as much as $6.179524(\mathrm{t}$-value $=$ 0.1032 ). This showed that there was no correlation in the residual as the p-values was higher than the significance value of $5 \%$. From the Durbin-Watson test, the statistic value was 1.65 and the value of $\mathrm{d}(\mathrm{k}=3$; $\mathrm{n}=25 ; \alpha=1 \%$ ) based on the DurbinWatson's table was 1.41. Thus, it could be concluded that there was no autocorrelation in the regression model as the DW value was between the value of $\mathrm{dU}$ and 4-dU.

From the multicolinearity test, it could be seen that the determinant coefficient value from the main regression model was 0.9869 which was higher than the value of determinant coefficient of the auxiliary regression model (X1, X2, X3, D1, D2, and D3). This indicated that with Klein's rule, there was no strong co-linearity between the independent variable. Based on those three classical assumption tests, the regression equation model was considered good as it met the classical assumption

Table 3. Results of diagnostic checking in linear regression model on micro and small scale coffee industries income

\begin{tabular}{|c|c|c|c|c|}
\hline \multirow{2}{*}{ Diagnostic checking } & \multirow{2}{*}{ Method } & \multicolumn{2}{|c|}{ Analysis results } & \multirow{2}{*}{ Result } \\
\hline & & Statistic & Value & \\
\hline \multirow{4}{*}{ Heteroskedasticity } & \multirow{4}{*}{$\begin{array}{l}\text { White } \\
\text { heteroskedasticity test }\end{array}$} & F-statistic & 0.720068 & \multirow{4}{*}{ No heterokedasticity } \\
\hline & & Probability & 0.6164 & \\
\hline & & Obs*R-squared & 3.982619 & \\
\hline & & Probability & 0.5519 & \\
\hline \multirow{7}{*}{ Autocorrelation } & \multirow{4}{*}{$\begin{array}{l}\text { Breusch-godfrey serial } \\
\text { correlation LM test }\end{array}$} & F-statistic & 1.751149 & \multirow{4}{*}{ No autocorrelation } \\
\hline & & Probability & 0.1970 & \\
\hline & & Obs*R-squared & 6.179524 & \\
\hline & & Probability & 0.1032 & \\
\hline & \multirow{3}{*}{ Durbin-Watson test } & Durbin-Watson Statistic & 1.653283 & \multirow{3}{*}{ No autocorrelation } \\
\hline & & $\mathrm{d}_{\mathrm{U}}(\mathrm{k}=3 ; \mathrm{n}=25 ; \mathrm{a}=1 \%)$ & 1,41 & \\
\hline & & $4-\mathrm{d}_{\mathrm{U}}$ & 2.59 & \\
\hline \multirow{7}{*}{ Multicolinearity } & \multirow{7}{*}{ Klein method } & $\mathrm{R}^{2} \mathrm{Y}$ & 0.986904 & \multirow{7}{*}{ No multicolinearity } \\
\hline & & $\mathrm{R}^{2} \mathrm{X}_{1}$ & 0.405852 & \\
\hline & & $\mathrm{R}^{2} \mathrm{X}_{2}$ & 0.447259 & \\
\hline & & $\mathrm{R}^{2} \mathrm{X}_{3}^{2}$ & 0.149051 & \\
\hline & & $\mathrm{R}^{2} \mathrm{D}_{1}^{3}$ & 0.063471 & \\
\hline & & $\mathrm{R}^{2} \mathrm{D}_{2}$ & 0.305649 & \\
\hline & & $\mathrm{R}^{2} \mathrm{D}_{3}^{2}$ & 0.031520 & \\
\hline
\end{tabular}


test. The diagnostic test's result as regression equation model for the micro and small scale coffee industries could be seen in Table 3 .

Implication of the analysis result was the need of support from local government and stakeholders to develop the micro and small scale coffee industries. Growth of this industry would be developed to make dynamically clustered coffee industry, thus it could increase the income of industry actors and other economic actors who supported the growth of clustered industry. The strategy to develop the clustered industry could be done by program facilitation and companionship to the business actors in expanding the product scale and marketing of the product.

\section{CONCLUSION}

The main motivation of the industry actors of micro and small scale coffee industries to start and develop their business is financial incentive. The incentive is aimed at gaining added-value of the product and earning more income. The indicator which can explain the entrepreneurship motivation is expectation, motive, and incentive, respectively. The regression analysis shows that the raw material and technology affect positively to the industry's income with reliability rate as much as $99 \%$. Meanwhile, market reach affects significant positively to the industry's income. The business experience significantly affects negatively to the industry income. On the other side, wages and capital source do not affect the industry income.

\section{ACKNOWLEDGEMENT}

The authors express their gratitude to the Agency for Forestry and Estate Crop Extention Services of Bondowoso district and Bank of Indonesia in Jember for contributing in form of funding and implementation of this study. The authors also appreciate Indonesian
Coffee and Cacao Research Institute for the technology guiding to improve quality and marketing system in farmer level.

\section{REFFERENCES}

Asnur, D. (2010). Penyusunan instrumen dan pembangunan sistem informasi data dasar koperasi dan UKM terpilih. Jurnal Pengkajian KUKM, 5, 119-144.

Almilia, L.S.; N. Shonhadji \& Angraini (2009). Faktor-faktor yang mempengaruhi financial sustainability ratio pada bank umum swasta nasional non devisa periode 1995-2005. Jurnal Akuntansi dan Keuangan, 11, 42-52.

Barba-Sánchez, V. \& C. Atienza-Sahuquillo (2012). Investigaciones Europeas de Dirección y Economía de la Empresa, $18,132-138$

BI Jember \& Puslitkoka (2010). Kajian Pembentukan Klaster Industri Kopi di Kabupaten Bondowoso. Kerjasama Bank Indonesia Jember dengan Pusat Penelitian Kopi dan Kakao Indonesia. Laporan Internal.

Ghozali, I. (2005). Aplikasi Analisis Multivariate dengan Program SPSS. Badan Penerbit Universitas Diponegoro, Semarang.

Juniarti \& R. Limanjaya (2005). Mana yang lebih memiliki value-relevant: net income atau cash flows (studi terhadap siklus hidup organisasi). Jurnal Akuntansi dan Keuangan, 7, 22-42.

Kotler, P. \& G. Armstrong (2004). Dasar-dasar Pemasaran. Penerjemah: Alexander Sindoro. Indeks, Jakarta.

Kristiyanti, M. (2012). Peran strategis usaha kecil menengah (UKM) dalam pembangunan nasional. Majalah Ilmiah Informatika, 3, 63-89.

Kurniawan, A. (2008). Faktor-Faktor Yang Mempengaruhi Produksi dan Pendapatan Usaha Mikro dan Kecil (Studi Kasus Industri Sepatu di Desa Sukaluyu Kecamatan Tamansari 
Kabupaten Bogor). Skripsi, Institut Pertanian Bogor, Bogor, Indonesia.

Munizu, M. (2010). Pengaruh faktor-faktor eksternal dan internal terhadap kinerja usaha mikro dan kecil (UMK) di Sulawesi Selatan. Jurnal Manajemen dan Kewirausahaan, 12, 33-41.

Nurhayati, N.; M. Hubeis \& S. Raharja (2012). Kelayakan dan strategi pengembangan usaha industri kecil tahu di Kabupaten Kuningan, Jawa Barat. Jurnal Manajemen IKM, 7, 111-121.

Nursiah \& F. Radhi (2009). Pengaruh penerapan strategi inovasi terhadap kinerja operasional. Jurnal Akuntansi dan Manajemen, 20, 69-77.

Prasetyo, P.E. (2007). Hubungan struktur pasar dan perilaku pasar serta pengaruhnya terhadap kinerja pasar. Jurnal Ekonomi Pembangunan, 12, 111-122.

Purnama, C. \& Suyanto (2010). Motivasi dan kemampuan usaha dalam meningkatkan keberhasilan usaha industri kecil (studi pada Industri Kecil Sepatu di Jawa Timur). Jurnal Manajemen dan Kewirausahaan, 12, 177-184.

Rosadi (2012). Ekonometrika \& Analisis Runtun Waktu Terapan dengan Eviews. Andi Offset,Yogyakarta.

Rose, T.M. \& K. Manley (2011). Motivation toward financial incentive goals on construction projects. Journal of Business Research, 64, 765-773.

Santosa, P.B. \& Ashari (2007). Analisis Statistik dengan Microsoft Excel \& SPSS. Andi Publisher, Yogyakarta.
Suradisastra, K.; Suherman \& A. Dariah (2014). Inovasi kreatif untuk membangun daya saing komoditas pertanian. In: Memperkuat Daya Saing Produk Pertanian. IAARD Press, Badan Litbang Pertanian, Kementerian Pertanian. Jakarta.

Utomo, S.B. \& B. Siregar (2008). Pengaruh ukuran perusahaan, profitabilitas, dan kontrol kepemilikan terhadap perataan laba pada perusahaan manufaktur yang terdaftar di Bursa Efek Indonesia (BEI). Jurnal Akuntansi dan Manajemen, 19, 113-125.

Walker, E. \& A. Brown (2004). What success factors are important tosmall business owners?. International Small Business Journal, 22, 577-594.

Wijaya, T. (2008). Kajian model empiris perilaku berwirausaha UKM DIY dan Jawa Tengah. Jurnal Manajemen dan Kewirausahaan, 10, 93-104.

Witjaksono, M. (2010). Modal sosial dalam dinamika perkembangan sentra industri logam Waru Sidoarjo. Jurnal Ekonomi Pembangunan, 11, 266-291.

Yunal, V.O. \& R. Indriyani (2013). Analisa pengaruh motivasi berwirausaha dan inovasi produk terhadap pertumbuhan usaha kerajinan gerabah di Lombok Barat. AGORA, 1, 1-11.

Yushuai, W.; Y. Na \& W. Changping (2014). An analysis of factors which influence entrepreneurial motivation focused on entrepreneurs in Jiang Xi Province in China. Journal of Applied Sciences, 14, $767-775$.

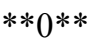

